\author{
Удк 332.2.021.8:352/354 \\ JEL classification: H72, Q15

\section{Орислава КОРКУНА} \\ кандидат економічних наук, \\ кафедра готельно-ресторанного бізнесу, \\ Львівський державний університет \\ фізичної культури імені І. Боберського, \\ Україна \\ E-mail: grafskayaorislava@gmail.com \\ https://orcid.org/0000-0002-8134-3771
}

\section{Олександр СЕЛІВОНЧИК \\ аспірант, \\ Львівський університет бізнесу та права, Україна \\ E-mail: sasha.selivvvon@gmail.com https://orcid.org/0000-0001-6341-5818 \\ (C) Орислава Коркуна, Олександр Селівончик, 2020}

Отримано: $30.01 .2020 \mathrm{p}$

Прорецензовано: 08.02.2020 p.

Рекомендовано до друку: 26.02.2020 p.

Опубліковано: 28.02.2020 p.

\section{(1) $\$$}

Ця стаптя розповсюджується на умовах ліцензії Creative Commons AttributionNonCommercial 4.0, яка дозволяє необмежене повторне використання, розповсюдження та відтворення на будь-якому носії, за умови правильного цитування оригінальної роботи.
Орислава Коркуна (Україна)

олександр Селівончик (Україна)

\section{СУЧАСНІ ОСОБЛИВОСТІ ІНСТИТУЦІЙНО-}

\section{ОРГАНІЗАЦІЙНОГО СЕРЕДОВИЩА РОЗВИТКУ СФЕРИ ТУРИЗМУ В ТЕРИТОРІАЛЬНИХ ГРОМАДАХ}

\author{
АнОТАЦІя
}

Вступ. Оцінити розвиток сфери туризму та рекреації в територіальних громадах, виявити проблеми, пов'язані 3 формуванням у громадах сприятливого середовища для туристів і рекреантів, а також розкрити переваги та недоліки інституційно-організаційного середовища розвитку туризму, можливо, якщо розглядати територіальну громаду як цілісну туристичну дестинацію. Основними ж елементами правового забезпечення розвитку сфери туризму в громаді $€$ правові та нормативні акти органів державної влади та органів місцевого самоврядування.

Мета. Метою статті $\epsilon$ аналіз особливостей та визначення проблеми інституційно-організаційного середовища розвитку сфери туризму і рекреації в територіальних громадах у сучасних умовах.

Методи. У статті використано методи діалектичної та формальної логіки для вивчення сутності інституційно-організаційного середовища розвитку сфери туризму в територіальних громадах; метод бенчмаркінгу визначення ефективності впроваджених реформ у формування місцевого самоврядування та; статистичні методи - для візуалізації та організації даних; структурні методи для оцінки наявних процесів розвитку туристичної сфери та визначення їх основних проблем.

Результати. У статті досліджено нормативно-правове середовище розвитку сфери туризму і рекреації в територіальних громадах. Виділено нормативно-правові акти, які мають безпосереднє і опосередковане відношення до досліджуваної проблеми. В розрізі досліджуваних територіальних громад згруповано основні проблеми розвитку туризму та рекреації, які були сформовані на основі опитування опитування вітчизняних i іноземні туристів. Обґрунтовано причинами невдалої реалізації проєктів державно-приватного партнерства у сфері туризму та рекреації в територіальних громадах. Досліджено процес та досвід організації туристичної діяльності в громадах на кластерних засадах, зокрема тих, які на ринку функціонують уже довго і тих, які почали тільки утворюватися. Визначеної їх особливості та перспективи розвитку. Серед характерних прикладів можна навести як кластери з тривалою історією функціонування, так і нещодавно сформовані. На основі проведеного аналізу розвитку і функціонування туристичних кластерів в Україні запропоновано основні напрями розвитку цієї сфери в територіальних громадах.

Коркуна О., Селівончик О. Сучасні особливості інституційно-організаційного середовища розвитку сфери туризму в територіальних громадах. Економічний аналіз. 2020. Том 30. № 1. Частина 2. С. 198-208.

DOI: https://doi.org/10.35774/econa2020.01.02.198

Ключові слова: туризм; територіальна громада; законодавча база; інституціональне забезпечення; кластери. 


\section{UDC 332.2.021.8:352/354}

\section{JEL classification: H72, Q15}

\section{Oryslava KORKUNA}

$\mathrm{PhD}$ in Economics,

Department of Hotel Restaurant Business, I. Boberskyi Lviv State University of Physical Culture, Ukraine

E-mail: grafskayaorislava@gmail.com https://orcid.org/0000-0002-8134-3771

\section{Oleksandr SELIVONCHYK}

PhD student,

Lviv University of Business and Law, Ukraine E-mail: sasha.selivvvon@gmail.com https://orcid.org/0000-0001-6341-5818

C Oryslava Korkuna, Oleksandr Selivonchyk, 2020

Received: 30.01 .2020

Revised: 08.02.2020

Accepted: 26.02.2020

Online publication date: 28.02 .2020

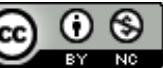

This is an Open Access article, distributed under the terms of the Creative Commons AttributionNonCommercial 4.0 license, which permits unrestricted re-use, distribution, and reproduction in any medium, provided the original work is properly cited.
Oryslava Korkuna (Ukraine)

Oleksandr Selivonchyk (Ukraine)

\section{MODERN FEATURES OF THE} INSTITUTIONAL AND

\section{ORGANIZATIONAL ENVIRONMENT OF TOURISM DEVELOPMENT IN TERRITORIAL COMMUNITIES}

\section{ABSTRACT}

Introduction. Assessment of the development of tourism and recreation in local communities, identifying problems associated with the formation of a favorable environment for tourists and vacationers, as well as revealing the advantages and disadvantages of the institutional and organizational environment of tourism are possible only if we consider the local community as a holistic tourist destination. The main elements of legal support for the development of tourism in the community are legal and regulatory acts of public authorities and local governments.

The purpose of the article is to analyze the features and identify the problems of institutional and organizational environment for the development of tourism and recreation in local communities in modern conditions.

Methods. The authors used the methods of dialectical and formal logic in the article for study the essence of the institutional and organizational environment of tourism development in territorial communities; benchmarking method for determining the effectiveness of implemented reforms in the formation of local self-government; statistical methods for data visualization and organization; structural methods for assessing the existing processes of development of the tourism sector and identifying their main problems.

Results. The article examines the legal environment for the development of tourism and recreation in local communities. The normative-legal acts which have a direct and indirect relation to the researched problem are allocated. In the context of the studied territorial communities, the main problems of tourism and recreation development are grouped based on a survey of domestic and foreign tourists. The reasons for the unsuccessful implementation of publicprivate partnership projects in the field of tourism and recreation in territorial communities are stipulated. The process and experience of organizing tourist activities in communities on a cluster basis, in particular those that have been operating in the market for a long time and those that have just begun to form, are studied. Their features and prospects for development are defined. Typical examples include clusters with a long history of operation, as well as recently formed ones. Based on the analysis of the development and functioning of tourism clusters in Ukraine, the main directions of development of this area in territorial communities are proposed.

Korkuna, O., \& Selivonchyk, O. (2020). Modern features of the institutional and organizational environment of tourism development in territorial communities. Economic analysis, 30 (1, Part 2), 198-208.

DOI: https://doi.org/10.35774/econa2020.01.02.198

Keywords: tourism; territorial community; legal framework; institutional support; clusters. 
www.econa.org.ua

\section{Вступ}

Складовими інституційно-організаційного середовища функціонування та розвитку сфери туризму i рекреації $€$ правове забезпечення, інституції, які прямо чи опосередковано здійснюють управління та впливають на розвиток туризму та рекреації на рівні територіальних громад, а також організаційний механізм реалізації політики у сфері туризму та рекреації.

Правове забезпечення встановлює фундаментальні принципи функціонування туризму та рекреації і має на меті створити умови для реалізації прав і дотримання обов'язків усіма суб'єктами сфери туризму та рекреації (надавачами туристичних послуг, послуг 3 розміщення i перевезення, туристами та рекреантами, органами влади та місцевого самоврядування, громадськими організаціями та ін.). Елементами правового забезпечення $€$ правові та нормативні акти органів державної влади та органів місцевого самоврядування.

\section{Мета статті}

Метою статті $\epsilon$ аналіз особливостей та визначення проблеми інституційно-організаційного середовища розвитку сфери туризму і рекреації в територіальних громадах у сучасних умовах.

\section{Виклад основного матеріалу}

До основоположних правових актів, які регулюють сферу туризму та рекреації, і на основі яких вибудовують свій розвиток у цій сфері територіальні громади, належать:

- Конституція України, у якій закріплено права та свободи громадянина (у тому числі право на відпочинок, вільне пересування, безпечне для життя і здоров'я довкілля, задоволення духовних потреб тощо), а також встановлено обов'язковість виконання на території територіальної громади рішень органу їі місцевого самоврядування [1];

- Закон України «Про туризм», яким визначено загальні правові, організаційні та соціальноекономічні засади реалізації державної політики у сфері туризму, а також врегульовано відносини щодо організації та здійснення туризму на території України [2];

- Закон України "Про курорти», який визначає правові, організаційні, економічні та соціальні засади розвитку курортів і який спрямований на забезпечення оздоровлення людей шляхом використання природних лікувальних ресурсів i природних територій курортів, а також їх охорони [3].

Окрім зазначених, існує низка правових i нормативних актів, які опосередковано - через встановлення засад функціонування суб'єктів господарювання - регулюють сферу туризму та рекреації, зокрема: Господарський кодекс України, Податковий кодекс України, Бюджетний кодекс України, Закон України «Про підприємства в Україні», порядок встановлення категорій готелям та іншим об'єктам, що призначаються для надання послуг з тимчасового розміщення (проживання) та інші.

Інституціями, які покликані сприяти розвитку туризму на рівні територіальних громад, $€$ органи місцевого самоврядування. Так, у межах своїх повноважень сільські, селищні та міські ради: затверджують місцеві програми розвитку туризму; визначають кошти місцевих бюджетів для фінансового забезпечення місцевих програм розвитку туризму; доручають своїм виконавчим органам фінансування місцевих програм розвитку туризму за рахунок коштів місцевого бюджету; вживають заходи для стимулювання суб'єктів господарювання, які здійснюють діяльність 3 надання туристичних послуг [4] тощо.

Безпосередньо ж відповідальними за розроблення та виконання місцевих програм розвитку туризму та рекреації $€$ виконавчі органи місцевого самоврядування (виконавчі комітети місцевих рад). У межах свої повноважень останні організовують проведення інвентаризації туристичних ресурсів територіальної громади, сприяють їх охороні та збереженню. У територіальних громадах, які вбачають у туристичній галузі одну з пріоритетних галузей розвитку економіки громади, можуть створюватись у складі виконавчих органів місцевого самоврядування спеціальні підрозділи, які курують питання туризму і рекреації. Так, у м. Яремче питання розвитку туризму покладено на відділ туризму та зовнішніх зв'язків міськвиконкому; у Славській ОТГ - на відділ туризму та комунікацій Славської селищної ради; у Шабівській ОТГ - на відділ економіки, рекреаційної діяльності, туризму та інвестиційної політики і т. ін.

Основна роль органів місцевого самоврядування в розвитку туризму і рекреації в територіальних громадах обумовлена також їхніми повноваженнями, які безпосередньо не пов'язані зі сферою туризму, але мають вплив як на функціонування суб'єктів підприємництва, так і на популярність громади як туристичної дестинації. Серед них: встановлення місцевих податків і зборів, зонування території місцевої громади, забезпечення розвитку житлово-комунального та дорожнього господарств у громаді тощо.

Проте найважливішим аспектом діяльності органів місцевого самоврядування (зокрема виконавчих комітетів місцевих рад) у напрямі розвитку туризму та рекреації в територіальних громадах, на нашу думку, $€$ їхня взаємодія 3 суб'єктами господарювання (підприємствами, установами, організаціями), діяльність яких прямо чи опосередковано пов'язана зі сферою туризму та 
www.econa.org.ua

рекреації, а також мешканцями громади для вирішення проблем і визначення пріоритетів розвитку туризму в громаді.

Налагодження співробітництва з бізнесовими структурами та громадськістю відбувається за допомогою організаційного механізму розвитку туризму та рекреації в місцевих громадах. Його головними елементами $€$ місцеві стратегії та програми розвитку туризму та рекреації, членство в туристичних асоціаціях, договори державноприватного партнерства, участь у туристичному кластері.

Стратегічні та/або програмні документи, які скеровані саме на розвиток туризму та рекреації, були затверджені органами місцевого самоврядування територіальних громад м. Моршина, м.Яремче (частково охоплювали і с. Поляниця, яке входить до складу Яремчанської міськради), Славської ОТГ, Шабівської ОТГ, Приморської ОТГ, Коблівської ОТГ, м. Львова, м. Одеси та м. Ужгорода. В інших територіальних громадах, які $\epsilon$ головним об'єктом нашого дослідження, заходи з розвитку туризму і рекреації були зазначені як один з напрямів у загальній стратегії соціально-економічного розвитку територіальної громади. А в с. Залізний Порт і с. Косонь такі документи не були розроблені.

Аналіз зазначених вище стратегічних i програмних документів досліджуваних територіальних громад, а також інформації на офіційних сайтах громад та оприлюднених у зMІ новин дозволяє виявити проблеми організаційного характеру, які гальмують розвиток і функціонування сфери туризму та рекреації, перешкоджають ефективному використанню туристичних ресурсів територіальної громади та не сприяють бажаному збільшенню туристичних потоків (таблиця 1). Так, усі виклики, які територіальним громадам необхідно подолати для покращення діяльності туристичної галузі, умовно можна поділити на: 1) ті, які безпосередньо пов'язані 3 туризмом та рекреацією; 2) ті, які наявні в суміжних сферах економіки, але чинять опосередкованих вплив на туристичну галузь. До першої групи належать: слабо розвинена пропозиція екскурсій на території громади; не вирішені питання безпеки туристів і рекреантів (зокрема на воді та в горах); слабо розвинена інфраструктура для активного відпочинку (вело-, мото-, автопрокату, спортивних атракцій тощо); відсутність у громадах туроператорів і турагентів, що негативно впливає на формування туристичного бренду громади та веде до втрати потенційних споживачів туристичних послуг громадою; недостатня кількість відповідно обладнаних об'єктів для відпочинку та розваг (пляжів, парків розваг, скверів тощо). Серед основних проблем другої групи варто виділити: брак пішохідних та велосипедних доріжок; відсутність організованих місць збору та вивозу сміття; недостатня кількість організованих місць для паркування автотранспорту; поганий стан дорожнього покриття в межах громади; недоліки інфраструктури з водопостачання і водовідведення; незадовільна якість води та ін. Доцільно також вказати ще на один суттєвий недолік в організації туризму і рекреації в територіальних громадах непристосованість інфраструктури громад для людей з особливими потребами. I хоча органи місцевого самоврядування досліджуваних громад не вказують у програмних документах цю проблему в переліку поряд 3 іншими невирішеними питаннями, проте в окремих туристичних дестинаціях (Моршин, Трускавець, Львів) вже виділяють кошти з місцевого бюджету на формування інфраструктури, придатної для людей з особливими потребами.

Доречно відзначити, що вказані вище проблеми відзначають в опитуваннях і іноземні туристи. Так, головними проблемами для зарубіжних гостей $\epsilon$ низький рівень сервісу в закладах харчування i торгівлі, громадського транспорту і таксі; незадовільний стан доріг; забрудненість місць громадського користування; труднощі з орендою житла; нерозвиненість індустрії розваг для дітей; невиправдано високі ціни, які не відповідають якості наданих послуг [5].

На подібні недоліки вказують і українські туристи: недостатній розвиток санаторно-курортної інфраструктури, що не відповідає сучасним потребам рекреантів; розташування міських пляжів у безпосередній близькості до морського порту (зокрема в Скадовську, Одесі та інших приморських містах); низька якість послуг і низький рівень обслуговування туристів і рекреантів; непристосованість закладів розміщення та громадських закладів для відвідування людей 3 особливими потребами; неналежна популяризація вітчизняних курортів тощо [6].

Розвитку і популяризації територіальної громади як туристичної дестинації, особливо серед внутрішніх туристів, сприяє участь громади (в особі органів місцевого самоврядування) у всеукраїнських туристичних організаціях та асоціаціях. Тому ми проаналізували кілька таких організацій на предмет участі в них територіальних громад, які $\epsilon$ головним об'єктом нашого дослідження. 


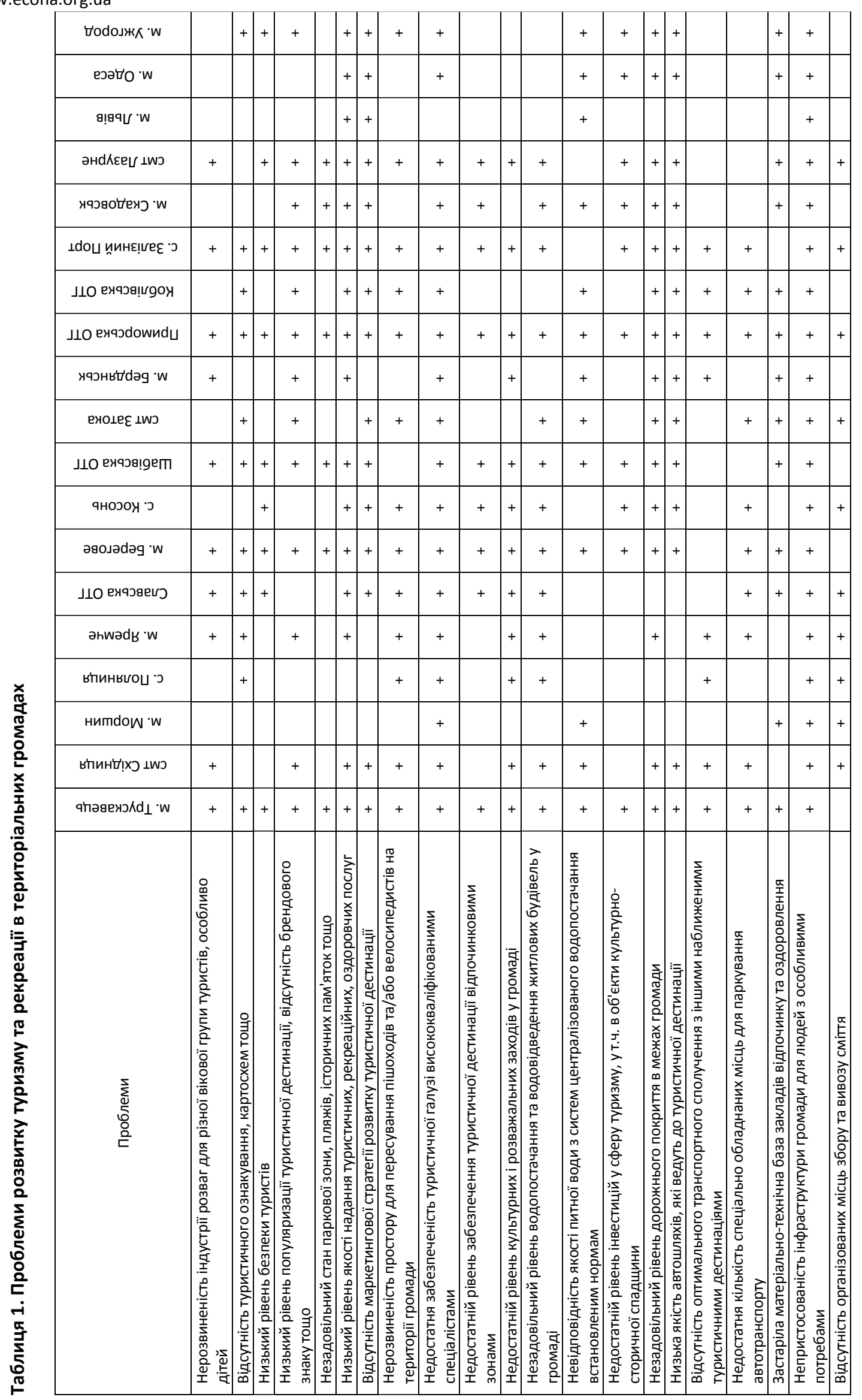


www.econa.org.ua

Першою 3 розглянутих нами всеукраїнських туристичних організацій $€$ Національна туристична організація України (НТОУ). Метою ії діяльності $\epsilon$ всебічний розвиток національної туристичної галузі в державі, а також координація та консолідація діяльності ії учасників для розвитку національного ринку туристичних і супутніх послуг і для захисту їх економічних інтересів. Серед напрямів діяльності НТОУ можна виділити: об'єднання зусиль суб'єктів інфраструктури туризму та органів влади і місцевого самоврядування; створення та просування, національного туристичного продукту; підтримка систем знань, освіти і професійної підготовки у сферу туризму; розвиток систем якості, аудиту та сертифікації в туристичній галузі тощо. Одним з основних засобів реалізації діяльності за вказаними напрямами $€$ просування регіонального та місцевого туристичних продуктів і сприяння дерегулюванню і саморегулюванню, налагодженню ефективної взаємодії держави, місцевого самоврядування, неприбуткових організацій і підприємців у сфері туризму [7].

Однак аналіз чинних учасників НТОУ показав низьку активність як органів місцевого самоврядування, так і регіональних і місцевих організацій туристичного спрямування. Так, до складу членів НТОУ у 2019 р. входили: Асоціація «Туризм Одеси», Асоціація «Туризм Херсона», Громадська організація «Асоціація лідерів туристичного бізнесу Миколаївської області», Громадська організація «Туристична асоціація Тернопілля» та інші; представники департаментів туризму Львівської, Херсонської, Миколаївської, Чернігівської обласних державних адміністрацій, а також Київської міської державної адміністрації; представники закладів вищої освіти Києва, Львова, Одеси, Житомира, Харкова, Донецька та інших міст; фізичні особи на правах асоційованих членів [8]. Проте органи місцевого самоврядування жодної 3 територіальних громад, які $\epsilon$ головним об'єктом нашого дослідження, не увійшли до складу членів НТОУ. Це можна вважати суттєвим недоліком у напрямі розвитку туризму і рекреації в туристичних дестинаціях, оскільки 2020 рік проголошено роком розвитку туризму в регіонах і сільських територіях. У зв'язку з цим НТОУ планує зосередити свою діяльність на наданні підтримки в проведенні фестивалів сільського туризму в територіальних громадах; проводити тренінги 3 розроблення туристичних продуктів сільського туризму в громадах; здійснювати заходи зі стимулювання місцевого малого бізнесу та жителів громад до об'єднання для сталого розвитку туризму у сільських територіях; надавати допомогу у створенні в громадах локальних компанії 3 маркетингу дестинацій за кластерною моделлю, туристичних інформаційних центрів, вказівників на туристичні атракції для орієнтування туристів тощо
[9]. Таким чином, територіальні громади можуть втратити одне з реальних джерел підтримки розвитку туристичної галузі.

Наступною 3 розглянутих нами туристичних організацій (щодо участі в ній представників територіальних громад) $€$ Українська асоціація активного та екологічного туризму (УАAЕT). УААЕТ спрямовує свою діяльність на популяризацію та розвиток дружніх природі активних видів відпочинку та екологічного туризму шляхом об'єднання усіх суб'єктів, зацікавлених у розвитку активного та екологічного туризму: бізнесових структур, громадських організацій, фізичних осіб, органів місцевого самоврядування та державної влади. Головними завданнями функціонування УАAЕТ $€$ сприяння стійкому розвитку туристичних територій і місцевих громад, допомога в кадровому забезпеченні і розвитку туристичної інфраструктури, збереження і раціональне використання природних та історико-культурних туристичних ресурсів тощо [10].

До складу учасників УААЕТ входять національні парки («Синевир», «Верховинський», «Нижньодніпровський», «Вижницький» та ін.), туристичні клуби (пішого та велотуризму), бази та комплекси відпочинку, туристично-інформаційний центр «Верховина» та інші суб'єкти інфраструктури туризму та рекреації. Проте, як і в попередньому випадку, серед учасників немає представників жодної територіальної громади.

І ще однією всеукраїнською організацією, яка надає підтримку розвитку туризму та рекреації в територіальних громадах, $€$ Всеукраїнська громадська організація Туристична асоціація України (ТАУ). На відміну від двох попередніх організацій, головний акцент у своїй діяльності ТАУ робить на об'єднанні власне суб'єктів інфраструктури туризму та суміжних галузей для спільного захисту їх прав, задоволення професійних і соціальних інтересів, а також сприянню розвитку туризму в Україні, у тому числі шляхом збереження й захисту культурної спадщини України. У 2019 р. ТАУ об'єднувала понад 350 провідних суб'єктів інфраструктури туризму зі всіх регіонів України. Слід відзначити, що з органами державної влади і місцевого самоврядування ТАУ співпрацює в напрямі підготовки проєктів законодавчих та інших нормативно-правових актів з питань туризму, забезпечення захисту прав суб'єктів інфраструктури туризму та туристів тощо [11].

Серед вагомих кроків, здійснених ТАУ в напрямі розвитку туризму в територіальних громадах, $\epsilon$ започаткований спільно з УААЕТ та тренінговим агентством «ASK» проєкт «Місто: Розвиток через туризм». Проєкт спрямований на туристичний розвиток малих і середніх міст, сіл і селищ України, шляхом їх перетворення на конкурентоспроможні туристичні дестинації через запровадження 
www.econa.org.ua

публічно-приватного партнерства. Учасниками проєкту можуть бути міста, селища, села, природні національні парки, великі туристичні атракції. У межах проєкту ТАУ надає консультації та допомогу в розробленні стратегічних документів з розвитку туризму в територіальних громадах (стратегій, програм і планів розвитку туризму), проводить тренінги з розвитку туризму в громадах, здійснює брендування та просування громади як туристичної дестинації тощо. Але знову ж таки варто вказати на пасивність органів місцевого самоврядування територіальних громад, які $\epsilon$ головним об'єктом нашого дослідження, щодо участі в проєкті «Місто: Розвиток через туризм».

Одним з елементів організаційного механізму розвитку туризму та рекреації в місцевих громадах $€$ державно-приватне партнерство (ДПП), оскільки, відповідно до Закону України «Про державноприватне партнерство», туризм, відпочинок і рекреація входять до переліку сфер співробітництва держави, територіальних громад і суб'єктів господарювання (приватного партнера), у тому числі фізичних осіб-підприємців (крім державних і комунальних підприємств, установ, організацій) на засадах державно-приватного партнерства [12]. Учасниками ДПП з боку держави можуть бути органи державної влади, органи місцевого самоврядування, державні та комунальні підприємства та установи. А з боку приватного партнера найбільш зацікавленими учасниками ДПП мали 6 бути підприємства та організації сфери туризму та рекреації: туроператори, турагенти, установи засобів розміщення, заклади харчування, компанії-перевізники, екскурсійні бюро, івенткомпанії і т. ін.

Основними формами реалізації державноприватного партнерства в Україні $€$ договори про спільну діяльність, концесію та оренду. Найвигіднішими для державного партнера $\epsilon$ договори концесії та оренди, оскільки в такому випадку основний тягар з ведення діяльності, здійснення інвестицій і прийняття ризиків несе приватний партнер, а право власності на об'єкт договору залишається за державним партнером.

Аналіз укладених договорів державноприватного партнерства в Україні свідчить про низький інтерес суб'єктів господарювання (приватних партнерів) до можливості зреалізувати свій потенціал у сфері туризму та рекреації. Так, на кінець 2019 р. на засадах ДПП загалом було укладено 187 договорів, 3 яких реально реалізувалося лише 52 договори (34 - договорів концесії, 16 - договорів про спільну діяльність, 2 інші договори), а 135 договорів не реалізувалися (у 4 договорах - закінчився термін дії, 18 договорів було розірвано, 113 договорів - не виконувалося). Водночас у сфері туризму реалізувалося лише три договори ДПП (два у Львівській області і один - у
Київській області). Найбільше ж договорів серед тих, які реалізувалися (21 договір, або 40,1\% усіх договорів, які реалізувалися у 2019 р.), становили угоди щодо проєктів зі збору, очищення та розподілу води [13].

Практика укладання угод державно-приватного партнерства у сфері туризму та рекреації в Україні в останнє десятиліття мала місце, однак здебільшого їх реалізація була невдалою. Серед таких проєктів варто виділити:

- договір концесії щодо замку XVII ст. у Старому Селі Пустомитівського району Львівської області, укладений 2010 р. між Львівською ОДА та ТОВ «Кріс» терміном на 49 р., за яким приватний партнер був зобов'язаний до 2013 р. вивести залишки замку з аварійного стану і відновити одну з двох веж, а до 2016 р. організувати на території замку історичний туристично-відпочинковий комплекс для проведення фестивалів, концертів і зустрічей. Однак жодних робіт концесіонер не виконав, обґрунтовуючи свою бездіяльність фінансовою кризою і браком коштів. Попри те, договір концесії досі не розірвано, оскільки коштів на виведення замку 3 аварійного стану В публічного партнера нема [14];

- договір концесії щодо палацу XIX ст. У с. Тартаків Сокальського району Львівської області, укладений також у 2010 р. на 49 років між Львівською ОДА та ФОП «Новосад», за яким концесіонер зобов'язувався вивести палац 3 аварійного стану і ввести в експлуатацію В якості туристичновідпочинкового центру. Проте, як і в попередньому випадку, жодних робіт концесіонер не провів, мотивуючи бездіяльність відсутністю коштів. Тому 2013 р. угоду було анульовано[15];

- договір концесії щодо будівлі комунального кінотеатру, який Сокальська районна рада Львівської області уклала у 2012 р. Концесіонер зобов'язався відремонтувати будівлю, організувати в приміщенні кінотеатру інтернеткафе, дитяче кафе та заклад з продажу книжкової продукції. Проте концесіонер не виконував обов'язків ані зі сплати концесійних платежів, ані 3 інвестування у відновлення кінотеатру. У результаті договір було розірвано в судовому порядку і зобов'язано ексконцесіонера сплатити на користь територіальної громади понад один мільйон гривень заборгованості за концесійними платежами, 175 тис. грн пені та 8 тис. грн штрафних санкцій [16].

Серед туристичних дестинацій-головних об'єктів нашого дослідження також мало місце укладання договору державно-приватного партнерства у сфері туризму та рекреації, але через 
www.econa.org.ua

недотримання органами місцевого

самоврядування норм законодавства проєкт зазнав невдачі. Так, Новофедорівська сільська рада Голопристанського району Херсонської області 2013 р. передала у концесію пляж у селі Залізний порт. Проте в процесі укладання договору концесії органом місцевого самоврядування було допущено низку юридичних помилок (безпідставно уповноважено на укладення договору комунальне підприємство, порушено вимоги щодо об'єкта концесії та порядку надходження концесійних платежів (на рахунок комунального підприємства замість до місцевого бюджету) та ін.), що спричинило до визнання договору в судовому порядку (за поданням прокуратури) недійсним і зобов'язало концесіонера повернути пляж сільській раді [16].

Однак варто відзначити, що в Україні $\epsilon$ й поодинокі приклади вдалої реалізації договорів державно-приватно партнерства у сфері туризму. Так:

- частини Мукачівського замку «Паланок» в Закарпатській області у 2010 та 2011 рр. були передані за договорами оренди на період до 2056 р. приватним інвесторам (2300 м² - ТОВ «Високий замок» (за 10 млн грн за весь період оренди) та підвальні приміщення СП «Айсберг») для створення готельноресторанного комплексу, дегустаційного залу, магазину з продажу вина та сувенірів[17];

- замок XIV ст. Сент-Міклош у смт. Чинадієво Мукачівського району Закарпатської області ще у 2001 р. був переданий в оренду фізичній особі Йосипу Бартошу. За договором оренди останній зобов'язувався створити культурномистецький центр і уберегти замок від руйнування. Сьогодні у замку функціонує туристичний інформаційний центр «СентМіклош», історико-краєзнавчий музей, концертний і конференц-зали, картинна галерея та зала для шлюбних церемоній. Водночас у замку тривають реставраційні роботи, які проводить орендар [18].

Головними причинами невдалої реалізації проєктів державно-приватного партнерства у сфері туризму та рекреації в територіальних громадах можна назвати:

- непривабливість для приватних партнерів значної частини об'єктів туристичної інфраструктури через необхідність вкладення в них значних фінансових ресурсів за невизначених термінів окупності проєкту;

- відсутність законодавчо закріпленої мінімальної частки фінансової участі у проєкті приватного партнера;

- неналежна фахова підготовка працівників державних органів виконавчої влади та органів місцевого самоврядування, які здійснюють підготовку і супровід договорів державноприватного партнерства;

- відсутність дієвих фінансових стимулів для приватних партнерів (наприклад, податкових канікул у перші роки реалізації проєкту) щодо участі у державно-приватному партнерстві;

- неналежне прогнозування з боку приватного партнера щодо обсягу інвестицій, необхідних для реалізації проєкту.

Ще одним напрямом розвитку територіальної громади як туристичної дестинації може стати формування в її межах або разом з подібними територіальними громадами регіону, які мають на своїх теренах туристичні ресурси, туристичного кластера.

Туристичний кластер формується на основі добровільного об'єднання суб'єктів інфраструктури туризму для підвищення конкурентоспроможності власної продукції та зростання привабливості туристичної дестинації та регіону загалом шляхом їх співпраці з органами державної влади, місцевого самоврядування та науковими установами. Характерною особливістю функціонування кластерів є те, що для досягнення цілей своєї діяльності суб'єкти кластера кооперують свої зусилля по вертикалі (наприклад, заклади 3 розміщення тісно співпрацюють 3 туристичними агентствами, закладами харчування, розважальними центрами тощо), водночас конкурують між собою по горизонталі (наприклад, з іншими закладами з розміщення). Для підтримки функціонування та розвитку кластера учасники здійснюють вступні та членські внески.

Створення та життєдіяльність туристичного кластера доволі часто залежить від ініціативності та кроків у цьому напрямі органів місцевого самоврядування, оскільки останні, як обрані громадою для управління представники, є однією 3 найбільш зацікавлених сторін у функціонуванні на території громади кластерного об'єднання. Адже туристичний кластер сприяє: збільшенню надходжень до місцевого бюджету через розширення податкової бази (насамперед щодо місцевих податків і зборів); підвищує інвестиційну привабливість територіальної громади, що позитивно впливає на зростання зацікавленості інвесторів щодо здійснення капіталовкладень у межах громади; зростанню зайнятості та збільшенню заробітної плати завдяки появі нових і розширенню наявних бізнесових структур; розвитку суміжних галузей економіки в територіальній громаді. Саме тому органи місцевого самоврядування першочергово мають орієнтуватися не на підтримку окремих суб'єктів господарювання (навіть найбільших платників податків до бюджету місцевої громади), а на сприяння організації галузевих кластерів і 
www.econa.org.ua

підтримання доброчесних взаємовідносин та конкуренції всередині кластера.

В Україні $€$ досвід організації туристичної діяльності в громадах на кластерних засадах. Серед характерних прикладів можна навести як кластери 3 тривалою історією функціонування, так і нещодавно сформовані:

- кластер еко-агротуризму «Оберіг» у смт Гриців Шепетівського району Хмельницької області) створений у 2002 р., об'єднав 60 представників сільських господарств для розвитку сільського туризму на основі інноваційних технологій;

- кластер пізнавального туризму «Південне туристичне кільце» був створений у 2004 р. на основі добровільного об'єднання органів місцевого самоврядування міст Одеської, Миколаївської та Херсонської областей (у 2004 р. ще й м. Алупки АР Крим);

- етнографічно-екологічний кластер «Бойківські ґазди» у Сколівському районі Львівської області започаткований у 2017 р. за підтримки Спілки сприяння розвитку сільського зеленого туризму в Україні «Сільський зелений туризм - від роз'єднаних садиб до територіальних кластерів» (у межах проєкту ПРООН в Україні «Зміцнення бізнес-об'єднань малих і середніх підприємств» та проєкту USAID «Програма підтримки аграрного і сільського розвитку») i налічував 43 учасники;

- агротуристичний кластер «ГорбоГори» створений у 2017 р. у Пустомитівському районі Львівської області на території Семенівської сільської ради та Солонківської ОТГ з ініціативи місцевих фермерів тваринницької спеціалізації, органів місцевого самоврядування, державної влади регіонального рівня, наукових i навчальних установ.

Ретроспективний аналіз показав, що в територіальних громадах, які є основним об'єктом нашого дослідження, кластерні ініціативи органів місцевого самоврядування доволі слабкі. Свідченням цього $\epsilon$ відсутність у стратегічних і програмних документах з розвитку туризму та рекреації, розроблених органами місцевого самоврядування більшості цих громад, намірів щодо створення туристичного кластера або приєднання до уже створеного.

Аналіз розвитку і функціонування туристичних кластерів в Україні дозволив зробити такі висновки:

- можливості для формування туристичного кластера мають практично усі територіальні громади, навіть ті, у яких немає чітко виражених туристичних ресурсів (підтвердженням $€$ досвід агротуристичного кластера «ГорбоГори»);

- переважно туристичні кластери побудовані за класичною структурою, яка включає усіх суб'єкти інфраструктури туризму, а також органи місцевого самоврядування та навчальні заклади;

- відсутність у складі кластера сторін, які надають супровід, підтримку та сприяння, гальмує розвиток туристичного кластера або спричиняє до його занепаду;

- фінансова підтримка з боку органів місцевого самоврядування щодо популяризації туристичного кластера на старті його розвитку $\epsilon$ однією $з$ передумов успіху функціонування кластера;

- активна діяльність туристичного кластера дозволяє органам місцевого самоврядування вирішувати проблеми громади (підвищити зайнятість, наповнення місцевого бюджету, покращити інфраструктуру в громаді, підвищити інвестиційну привабливість громади тощо);

- органи місцевого самоврядування територіальних громад Карпатського регіону, які орієнтуються на гірський туризм, швидше активізувалися щодо створення туристичних кластерів після схвалення урядом Стратегії розвитку туризму та курортів на період до 2026 р., ніж територіальні громади узбережжя Чорного та Азовського морів.

\section{Висновки та перспективи подальших досліджень}

Таким чином, проведений аналіз інституційноорганізаційного середовища розвитку і функціонування туризму та рекреації дозволяє стверджувати, що більшість 3 досліджуваних територіальних громад мають необхідне для розвитку сфери туризму нормативно-правове та інституційне забезпечення. Однак органами місцевого самоврядування слабо використовуються усі можливості організаційного механізму розвитку туризму та рекреації, а саме: участь у туристичних асоціаціях, що сприяло б популяризації та розвитку територіальної громади, як туристичної дестинації; укладання договорів державно-приватного партнерства, яке 6 дало змогу покращити стан туристичних ресурсів територіальної громади; формування туристичних кластерів, які б об'єднали зусилля усіх суб'єктів інфраструктури туризму як в самій громаді, так із господарюючими суб'єктами сусідніх територіальних громад.

Перспективами подальших досліджень $\epsilon$ розробка механізмів та визначення процесу імплементації європейського нормативногоправового забезпечення розвитку туристичної сфери в наші реалії в умовах формування територіальних громад. 


\section{www.econa.org.ua}

\section{СПИСОК ВИКОРИСТАНИХ ДЖЕРЕЛ}

1. Конституція України, від 28 червня 1996 року. URL: https://zakon.rada.gov.ua/laws/sho w/254\%D0\%BA/96\%D0\%B2\%D1\%80.

2. Закон України «Про туризм», 15 вересня 1995 року, № 324/95-ВР. URL:

https://zakon.rada.gov.ua/laws/sho w/324/95-

\%D0\%B2\%D1\%80/ed20181104\#Tex

3. Закон України «Про курорти», 5 жовтня 2000 року, № 2026-III. URL: https://zakon.rada.gov.ua/laws/sho w/2026-14.

4. Закон України «Про туризм», 15 вересня 1995 року, № 324/95-ВР. URL:

https://zakon.rada.gov.ua/laws/sho w/324/95-

\%D0\%B2\%D1\%80/ed20181104\#Tex

5. Lb.Ua. 45\% иностранных туристов недовольны украинским сервисом. URL: https://lb.ua/culture/2015/09/01/3 14853_45_inostrannih_turistov_ned ovolni.html.

6. Яровий В. Ф. Стан та перспективи розвитку підприємств і дестинацій галузі туризму південного регіону. Економіка та держава. 2017. №11. C. 25-28.

\section{REFERENCES}

1. Constitution of Ukraine (1996). Retrieved from: https://zakon.rada.gov.ua/laws/sho w/254\%D0\%BA/96\%D0\%B2\%D1\%80 [in Ukrainian].

2. Verkhovna Rada of Ukraine (1995) Law of Ukraine "On Tourism", September 15, № 324/95-VR Retrieved from: https://zakon.rada.gov.ua/laws/sho w/324/95-

\%D0\%B2\%D1\%80/ed20181104\#Tex $\mathrm{t}$ [in Ukrainian].

3. Verkhovna Rada of Ukraine (2000). Law of Ukraine "On Resorts", October 5, № 2026-III. Retrieved from:

https://zakon.rada.gov.ua/laws/sho w/2026-14 [in Ukrainian]

4. Verkhovna Rada of Ukraine (1995). Law of Ukraine "On Tourism", September 15, № 324/95-VR. Retrieved from: https://zakon.rada.gov.ua/laws/sho w/324/95-

\%D0\%B2\%D1\%80/ed20181104\#Tex $\mathrm{t}$ [in Ukrainian].
7. Статут Громадської спілки «Національна туристична організація України». URL: http://www.ntoukraine.org/assets/f iles/03_NTOU_Statut.pdf.

8. Реєстри HTO України. URL: http://www.ntoukraine.org/ntoukra ine_registries_ua.html\#extTable117.

9. 2020 - Рік розвитку туризму в регіонах та сільських територіях. Режим доступу: http://www.ntoukraine.org/ntoukri ane_2020_ua.html.

10. Громадська організація «Українська Асоціація Активного та Екологічного Туризму». URL: http://www.uaeta.net.

11. Туристична Асоціація України. URL: http://www.tau.org.ua.

12. Закон України «Про державноприватне партнерство» від 1 липня 2010 року, № 2404-VI. URL: https://zakon.rada.gov.ua/laws/sho w/2404-17\#Text.

13. Стан здійснення ДПП в Україні. Міністерство розвитку економіки, торгівлі та сільського господарства. URL: https://www.me.gov.ua/Documents /Detail?lang=uk-UA\&id=9fc90c5e2f7b-44b2-8bf1-

1ffb7ee1be26\&title=StanZdiisnenni aDppVUkraini.

5. Lb.Ua (2015) \% of foreign tourists are dissatisfied with Ukrainian service. Retrieved from: https://lb.ua/culture/2015/09/01/3 14853_45_inostrannih_turistov_ned ovolni.html [in Ukrainian].

6. Yarovyy, V. (2017). Status and prospects of development of enterprises and destinations of the tourism industry of the southern region. Economy and state, 11, 2528. [in Ukrainian].

7. Charter of the Public Union "National Tourist Organization of Ukraine". (2019). Retrieved from: http://www.ntoukraine.org/assets/ $f$ iles/03_NTOU_Statut.pdf [in Ukrainian]

8. Registers of NGOs of Ukraine. (2017). Retrieved from: http://www.ntoukraine.org/ntoukra ine_registries_ua.html\#extTable117 [in Ukrainian].
14. Мартинів І. Пролітаючи над замком: Старе Село. URL: https://zbruc.eu/node/81114.

15. Папірник І. Крижанівська М. Якщо купити собі замок...Як працює формат концесії в Україні. URL: http://vikka.ua/novini/04186yakscho-kupiti-sobi-zamok---yakpratsyue-format-kontsesii-vukraini.htm

16. Коваль Ю. ТОП-10 нетипових об'єктів ДПП в Україні. URL: http://jurblog.com.ua/2017/07/top10-netipovih-obektiv-dpp-vukrayini.

17. Мальський М. Публічно-приватне партнерство: уроки минулого та перспективи майбутнього. URL: www.congress.lviv.ua/download.ph p?downloadid $=30$.

18. Гончарова К. Один у полі воїн: український художник Йосип Бартош підняв з руїн старовинний замок на Закарпатті. URL https://styler.rbc.ua/ukr/intervyu/io sif-bartosh-v-zakarpate-trinadtsatzamkov-1467579899.html.

9. 2020 - Year of tourism development in regions and rural areas. (2020). Retrieved from: http://www.ntoukraine.org/ntoukri ane_2020_ua.html [in Ukrainian]

10. Public organization "Ukrainian Association of Active and Ecological Tourism". (2020). Retrieved from: http://www.uaeta.net/ [in Ukrainian].

11. Tourist Association of Ukraine. (2020). Retrieved from: http://www.tau.org.ua [in Ukrainian].

12. Verkhovna Rada of Ukraine (2010) Law of Ukraine "On Public-Private Partnership" of July 1, № 2404-VI. Retrieved from: https://zakon.rada.gov.ua/laws/sho w/2404-17\#Text [in Ukrainian] 
www.econa.org.ua

13. Status of PPP implementation in Ukraine. Ministry of Economic Development, Trade and Agriculture. (2019). Retrieved from: https://www.me.gov.ua/Documents /Detail?lang=uk-UA\&id=9fc90c5e2f7b-44b2-8bf1-

1ffb7ee1be26\&title=StanZdiisnenni aDppVUkraini [in Ukrainian].

14. Martyniv, I. (2014). Flying over the castle: Old Village. Retrieved from: https://zbruc.eu/node/81114 [in Ukrainian].
15. Papirnyk, I., \& Kryzhanivska, M. (2018). If you buy a castle ... How the concession format works in Ukraine. Retrieved from: http://vikka.ua/novini/04186yakscho-kupiti-sobi-zamok- --yakpratsyue-format-kontsesii-vukraini.htm [in Ukrainian].

16. Koval, Yu. (2017). TOP-10 atypical objects of PPP in Ukraine. Retrieved from:

http://jurblog.com.ua/2017/07/top10-netipovih-obektiv-dpp-vukrayini/ [in Ukrainian]
17. Public-private partnership: lessons of the past and prospects of the future. (2019). Retrieved from: www.congress.lviv.ua/download.ph p?downloadid=30 [in Ukrainian].

18. Goncharova, K. (2009). One warrior in the field: Ukrainian artist Joseph Bartosh raised from the ruins of an ancient castle in Transcarpathia. Retrieved from: https://styler.rbc.ua/ukr/intervyu/io sif-bartosh-v-zakarpate-trinadtsatzamkov-1467579899.html Ukrainian]. 